\title{
筑豊山田における大手企業の炭鉱集落建設過程 THE BUILDING PROCESS OF COAL MINING SETTLEMENTS BY BIG BUSINESSES IN YAMADA TOWN, CHIKUHO
}

\author{
安武敦子*, 菊地成朋** \\ Atsuko YASUTAKE and Shigetomo KIKUCHI
}

\begin{abstract}
The purpose is to clarify the building process of coal mining settlements by comparing 2 mines. As a result, hills and damp grounds and so on that were low yield, were selected as the site, because there had been a riceproducing district in Chikuho region. The both areas were self-supporting planed, and insides had minimum establishments of life for them. Each supply of houses for coal miners from 1919 (after the world war I) to 1930 (before the Manchurian Incident ) was quite different in each personnel management system and a operating policy. In the period under control from 1931 to 1949 (the end of the world war II), the time selected by each company effected each form of settlement.

The coal mining settlements were related to the business strategy of each company, deeply.
\end{abstract}

Keywords : coal mine, coal mining settlement, naya-seido, housing management, personnel management 炭鉱, 炭鉱集落, 納屋制度, 住宅運営, 労務管理

\section{1. はじめに}

\section{研究目的}

筑豊地方は福岡県のほぼ中央に位置し，近世期には稲作を中心と する農村であった。近代以降, 北海道の空知地方と並ぶ日本有数の炭 田地帯となり，その中で炭鉱集落 $\left.{ }^{1}\right)$ が農村集落と折り合いを付けな がら形成される。炭鉱集落は, 管理・生産・居住そして福利厚生施設 が一体となった自己完結的な集落で,このなかでほとんどの労㗢者に 対して居住施設が用意されており,それが炭釷集落の際立つた特徵と なっている。

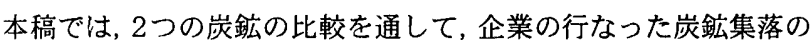
建設の実態を明らかにすることを目的としている。その際, 建設主体 である企業の地下条件や既存の農村集落の読み取り方, 生産の方針と それを受けた建設実態, 世論や国策に対する労務管理の変遷と集落運 営との関係, に着目して考察する。

なお，炭鉱集落の形成に関する現在までの研究は，駒木定正によ

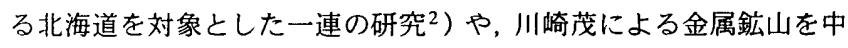
心とした鉱山集落研究がある $\left.{ }^{3}\right)$ 。駒木の主な研究対象は炭鉱関連建 築物全般であるが, 炭鉱集落についてもその地理的展開が検討されて いる。川崎は近代鉱山集落というよりは, 近世か.ら近代にかけての近 世鉱山集落に着目しており,技術革新と絡めて変容を考察している。

\section{研究対象}

対象とした 2 鈗は, 福岡県山田市にあった三菱上山巴鉣と古河下 山田鈗である。三菱上山田鈗は, 明治 28 年に操業を開始し, 昭和 37 年に閉山するまでの 67 年間, 一貫して三菱鉱業が経営している。古 河下山田鉱は, 明治 27 年から昭和 45 年までの 77 年間, 古河鈗業が 経営した。両者はそれぞれ山田内の1位，2位の優良鈗区を占め, 二 大炭鉱として推移する（図 1)。

三菱釷業は企業としては三井鉱山に続く規模であり，明治 14 年の 官営高島鉱 (長崎県) の払い下げを受けて以来, 炭鉱を次々と経営 し，全国に 15 鉱，うち筑豊に 5 鉱（昭和 30 年時点）の炭釷を所有 した。上山田鉱は三菱鉱業のなかでは小規模な部類に入る ${ }^{4}$ )。

古河釷業は銅山経営から始まり，炭鉱開発は銅の精錬燃料のため に着手する。下山田鉱が初の炭鉱経営で，昭和 30 年時点で全国に 6 鉱, うち筑豊に4鉱があった。各釷の生産規模の格差は三菱鉱業ほど 大きくない。

\section{研究方法}

炭鉱集落の空間構成の復元に際して, 閉山時については昭和 28 年 に発行された縮尺 3 千分の 1 の地図 ${ }^{5}$ ) および昭和 35 年の空中写真 から, 昭和初期については昭和 7 年の縮尺 1 万分の 1 の地図 $\left.{ }^{6}\right)$ と昭

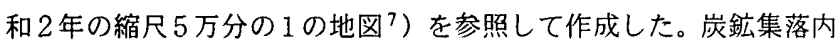

* 東京理科大学工学部建築学科 補手. 工修

** 九州大学大学院人間環境学研究院 教授.工博
Research Assistant, Faculty of Engineering, Science Univ. of Tokyo, M. Eng. Prof., Faculty of Human-Environment Studies, Kyushu Univ., Dr. Eng. 
の地区ごとの建設年代や施設名は, 史資料・聞取り調査・実測調査 · 個人の日記等によっている。昭和以前の状況については, 既存の調査 刊行物や回顧録・自伝などの諸資料から状況を類推した。

聞取り調查および実測調查は, 1993 年から 1999 年まで随時行 なっている。

\section{2. 時代区分}

分析にあたり, 明治から現在まで, 炭鉱産業の推移にしたがって 以下のように6つに区分した。

近代以降石炭は，初期には製塩業，次第に工場や船舶・鉄道燃料 として需要が高まり，筑豊では小規模な炭鉱開発が相次いだ。政府は 釷区の小規模化を危惧し，明治 15 年になると鉱区を 1 万坪以上に限 定 $\left.^{8}\right)$, 明治 21 年にはさらに最低 19 万坪, 計 1500 万坪の鉱区を農商 務省が選定・統合した。その大鉱区に中央資本が注目し, 鉱区が急速 に集中した。この，その後の素地が整うまでの時期を萌芽期（〜明治 26 年) とする。

明治後期以降, 明治 27 年の日清戦争, 明治 37 年の日露戦争, 大 正3年からの第一次大戦といった戦争を通して軍需が増し, 技術的に も，坑道の掘削技術や坑内排水処理・石炭運搬技術などが進展して， 坑内寿命が安定する。こうして石炭が基幹産業として確立する明治 27 年から大正 7 年を確立期とした。

大正 7 年に第一次大戦が終結すると, 反動恐慌が起こり, 昭和 6 年 の満州事変まで続く。この間（大正 8〜昭和 5 年）を停滞期とした。 小規模炭鉱は次々と閉山し，大正 9 年に 189 鉱あった炭鉱は昭和元 年には 99 鉱にまで減少した。

満州事变に始まる戦時体制への移行期に景気が回復していくなか で, 昭和 13 年には国による石炭統制が始まり，労働者の配置から資 材や資金の融資まで国の統制下に置かれた。この昭和 6 年から昭和 19 年を軍事統制期とする。

戦後は, 炭鉱業が復興の基幹産業として位置付けられ, 昭和 21 年 に「傾斜生産方式」が閣議決定する。この終戦から優遇措置が打ち切 られる昭和 24 年までを復興統制期とする。復興金融公庫は炭釷に対 して集中的な融資が行ない,その融資額は他の産業をはるかに淩ぐも のであった ${ }^{9}$ )。

優遇措置が打ち切られた昭和 25 年以降は縮小期とした。炭鉱は戦 時中の乱掘で大手炭鉱を中心に老朽化が目立ちはじめ, 合理化のなか で労働者のストライキが頻発し, 安定的な供給ができなくなる。需要 側が重油を志向しはじめ,ついに政府はエネルギー政策を転換し，昭 和 30 年代を中心に多くの炭鉱が閉山する。

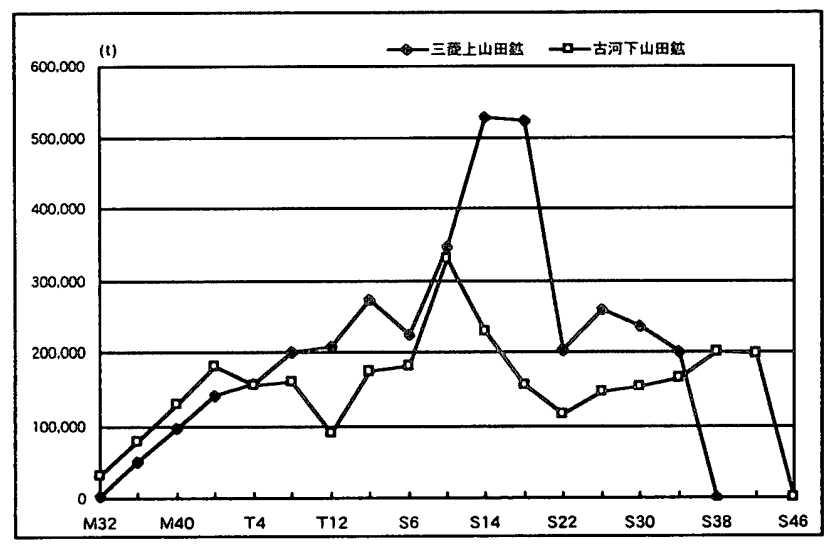

图 1 三菱上山田鉱・古河下山田鉱の出炭圈の推移

\section{3. 大手炭鉱の炭鉱集落建設 \\ 3-1 初期の鉱員住宅}

当初, 炭鉱集落の施設のうち鉱員住宅は企業が管理していなかつ た。多数の労働者を雇用・管理する技術が明治期にはまだなかったた め, 多くの産業で近世来の請負制度が採用された。とくに炭鉣では作 業管理と生活管理が分離され, 生活管理だけを職業とする納屋頭が登 場する。その管理システムを納屋制度と云い, 納屋制度では, 釷員の 募集・生活管理・給与支給などが納屋頭によって行なわれた ${ }^{10}$ )。納 屋制度は, 明治中期にジャーナリズムに批判 $\left.{ }^{11}\right)$ され，世論からも非 難されるが, 取り組み方や廃止時期は企業によって異なっている。筑 豊の大手企業で最も早い炭鈗は明治末期に実施し12），遅いものにな

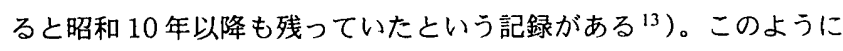
大手企業においても企業間でかなりの開きがあった。

三菱鉱業では, 大正 7 年に「納屋制度・飯場制度の廃占方針」が出 されたが $\left.{ }^{14}\right)$ ，実際には直轄制度にすぐに移行できていない。納屋制 度は継続し，一部で直轄世話方制度という，世話方が委任契約ではな く企業に雇われ，管理に企業が介在するシステムを取っている $\left.{ }^{15}\right) 。$ そして昭和 4 年に筑豊地域での納屋制度の完全廃止に踏み切る。三菱 鈗業の納屋制度の廃止は大手の中ではかなり遅い部類に入る。昭和 12 年には「詰所制度」が新設され，居住地が区に分割され，区ごと に区長が常駐する詰所が置かれ，区長と鉱員にはそ㧈までの主従関係 ではなく，親子や兄弟のような関係性が求められた $\left.{ }^{16}\right) 。$

古河鉱業は，明治末期から優良鉱夫表彰制度を実施したり，会社 が, 事務所・倉庫を提供して生活協同組合を設置するなど $\left.{ }^{17}\right)$, 釷員 管理へ企業が参画する時期が早い。同系列の足尾銅山では, 大正期に 直轄制度へ移行するために飯場頭（納屋頭）の雇用した鉣夫を 3 ケ月 で独立鉱夫にする制度が設けられ ${ }^{18}$ )，大正 9 年に飯場制度（納屋制 度）を解消している。聞き取り調查によると古河下山田鈗では, 昭和 初期には鉱員地区に区が設定され，鉱員間から区長が選出されていた という。これは三菱上山田鉱が昭和 12 年に実施した詰所制度と類似 している。古河釷業は三菱鉱業に比べて労務管理への取り組みが先行 していたと考えられる。

納屋頭の運営した居住地は, 納屋頭が大手炭釷間を転々としてい たことから ${ }^{19}$ )，炭鈗ごとの特徵はなかったと考えられる。文献等か ら，坑口付近に位置し，明治末期は 5 棟前後 ${ }^{20}$ )でひとまとまりにな $\left.り^{21}\right)$ ，それらが複数集まって炭釷集落の鉱員住宅地を形成していた と推測される。時代が下り鉱員が増えると, 納屋頭が増えるのではな く納屋頭の管理する住戸数が增え, 大正初期には棟数が約 10 倍に なったというテータがある22 $)$ 。納屋の建設に関しては, 明治期まで は, 企業の場合と納屋頭の場合とがあったが, 大正期に入ると, 企業 が鉱員住宅 (納屋) 建設に関与する割合が増える。それは，炭鉱労働 が, 採掘だけの単純労働から一定の技術を必要とするようになり，優 秀な鉱員を確保する必要がでてきたことによる。企業は技術力と勤続 年数とが相関しているとして, 鉱員の定住化を図る。住宅形式は家族 向けが主流になり，勤続年数の長い鉱員に衰賞を与える炭鉱が増え た。なかには優良鉱員に広い住戸を支給する炭鉱もでてきた $\left.{ }^{23}\right) 。$ 3-2 三菱上山田炭鉱における集落建設

一萌芽期（～明治 26 年）

上山田地域における炭層は, 山田川の東側の谷から北へ下ってい る。三菱鉱業の参入は明治 28 年で, 山田川東側一帯の鉱区を取得し 
た。それ以前に上山田地域に炭鉱がなかったのは，石炭の輸送が水運 であったため, 内陸に位㯰する山田は不向きであったことによる。 よって5つの農村集落と水田で構成されていた（図 2)。三菱上山田 鉱の炭鉱集落が立地した場所は，既存集落から離れた丘陵地や田地 で, 田地は, 明治 33 年の地形図 ${ }^{24}$ ) に地図記号で「沼田」と表わさ れており,地主への聞取り調査でも低湿な土地と云い, 農業的価値の 低い場所が選ばれている。

\section{一確立期（明治 $27 \sim$ 大正 7 年）}

当初は第一坑と第二坑からなり，第一坑が主力坑で, 駅と隣接し， 第二坑は南の谷の向集落（図2）付近にあった。確立期末頃の炭鉱集 落は，第一坑周辺はほぼ昭和 7 年と同程度（図 3）にまでなっていた と思われ $\left.{ }^{25}\right)$ ，第二坑周辺には納屋と職員住宅があったことが，後に 第二坑を買い取った炭鉱の資料から分かっている26)。炭鉱集落の中 心は主力坑である第一坑であり，居住地の他に，事務所・医務・購買 部 (3ヶ所) - 坑夫俱楽部 (32 坪) - 説教所 $(20$ 坪・僧侶 1 名) - 幼肾 預所 (37 坪・保母 15 名)・グランド等があった $\left.{ }^{27}\right)$ 。第一坑の周辺に 生産施設が置かれ, 炭鈗集落内の最も上山田駅寄りに事務所が位置し ている。購買部や坑夫俱楽部等の位置は分かっていないが, その後の 位置（図 4）とほぼ同じだと考えられる。第一坑の居住地は, 既存農 村部落とは反対の北側の谷に展開し, 計画中の竪坑の方へ延びてい る。鉱員住宅運営は, 大正 2 年時点でも納屋頭管轄の鉱員が約 9 割を 占め $\left.{ }^{28}\right)$, ほとんどの鉱員住宅が納屋頭に管理され，鈗員は納屋に住 んでいたと考えられる。また三菱鉱業では, 納屋頭が居住地の運営と ともに住宅建設も行なっていたと思われる。それは, 納屋制度を廃止 した際に鉱夫住宅建設を営繥課ではなく労務課が担当していることに よって判断される。労務課とは, 納屋制度下の中納屋頭や人繰が雇用 された課であり $\left.{ }^{29}\right)$ ，また建設業務が営繥課から労務課に移行すると は考えにくいため,もともと納屋頭の管轄下にあったと推測できる。 一停滞期（大正 $8 \sim$ 昭和 5 年)

新しい坑口として大正 13 年に竪坑が開坑する。この㹂坑は当時東 洋一の深度を誇り,生産面では第一坑以上に主力坑として位置付けら れる。しかし炭鉱集落は竪坑方向に延びているに過ぎず, 坑口移動に
よる集落移動は起きていないと云える。

炭鉱集落内では, 豎坑寄りと駅寄りに職員住宅が配置されている。 豎坑寄りの地区が大正時代に，駅寄り地区は昭和初期に建設されてい $\left.3^{30}\right)$ 。堅坑寄りの地区は, 敷地の標高は高いものの, 市街地からは 最も遠い。それに対し駅寄りの地区は既存の炭鉱集落と離れ，市街地 に連続した位置にある。一般に職員住宅建設において，市街地との近 さと標高の高さが考慮される傾向がある $\left.{ }^{31}\right) 。$ 㹂坑寄りの職員住宅が 建設された大正期には市街地がまだ発達しておらず, 市街地との関係 性ではなく地形的優位性で計画されたと考えられる。その後の職員住 宅建設は，市街地との距離がより優先される。

鉱員住宅は，一定の方向で整然と並んだ住棟からなる地区と，そ うでない地区があることが分かる。三菱上山田鈆では, 昭和 4 年まで 納屋制度と直轄世話方制度の 2 本立てで運営されている $\left.{ }^{32}\right)$ 。つまり， 居住地には企業経営と納屋頭経営のものがあり，それが形態の異なる 2種類の地区に対応していると考えられる。住宅における南面の重視 や住棟間隔の確保は，炭鉱においても衛生的な観点から明治末期頃か ら一般化しており,企業が建設したものにはそれが反映されると考え られる。

また，娛楽・厚生施設が，不況に伴う鉱員の労働運動に呼応して 建設されている。その位置は, 谷の結節部分で炭鉱集落のほぼ中心て あり,市街地と連動するのではなく，独立した集落の施設として計画 されていることが分かる。

\section{一軍需統制期（昭和 $6 \sim 19$ 年）}

三菱上山田鉱は昭和 17 年に過去最大の $536,311 \mathrm{t}$ を記録し，労働者 数は昭和 19 年に最高の 3,616 人となった。にもかかわらず，三菱上 山田鉱で炭鉱集落はあまり拡大していない。太平洋戦争に入る以前の 鉱員住宅は, 既存の釷員住宅地区の後背地やグランドなどに長屋形式 で建設されている。そのなかには2階建てなど実験的な住宅タイブも あった。この時期は，労務管理が詰所制度に移行した時期にあたり， 住宅建設に企業独自の試みが見受けられる。

太平洋戦争に入ると，熟練工が召集され，徽用労働者や女子鈗員· 外国人労働者などの未熟練工の大量投入によって増産が達成される。

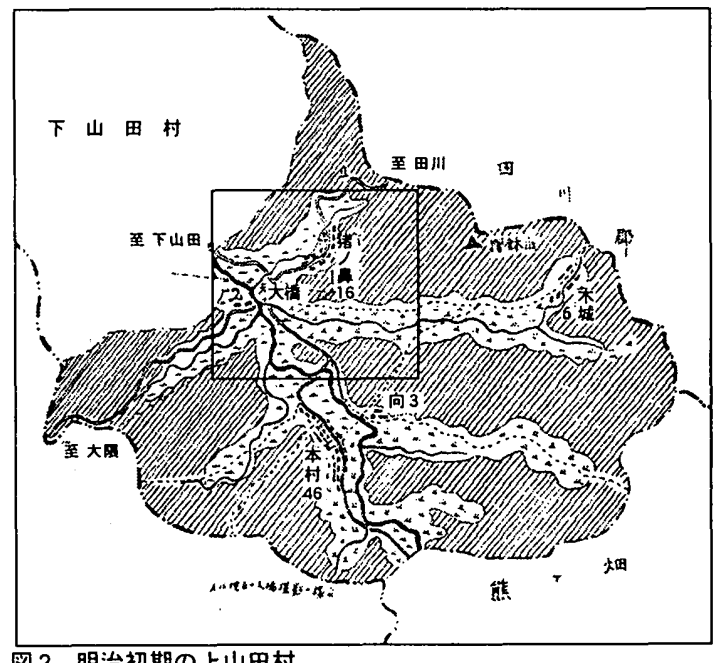

图 2 明治初期の上山田村

(『山田町誌』より，集落名，枠線は笔者挿入，図 3 の笔囲を示す) 凡例

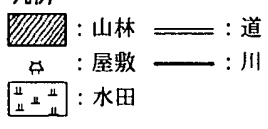

图 3 昭和 7 年の三菤上山田鉱 炭鉱集落

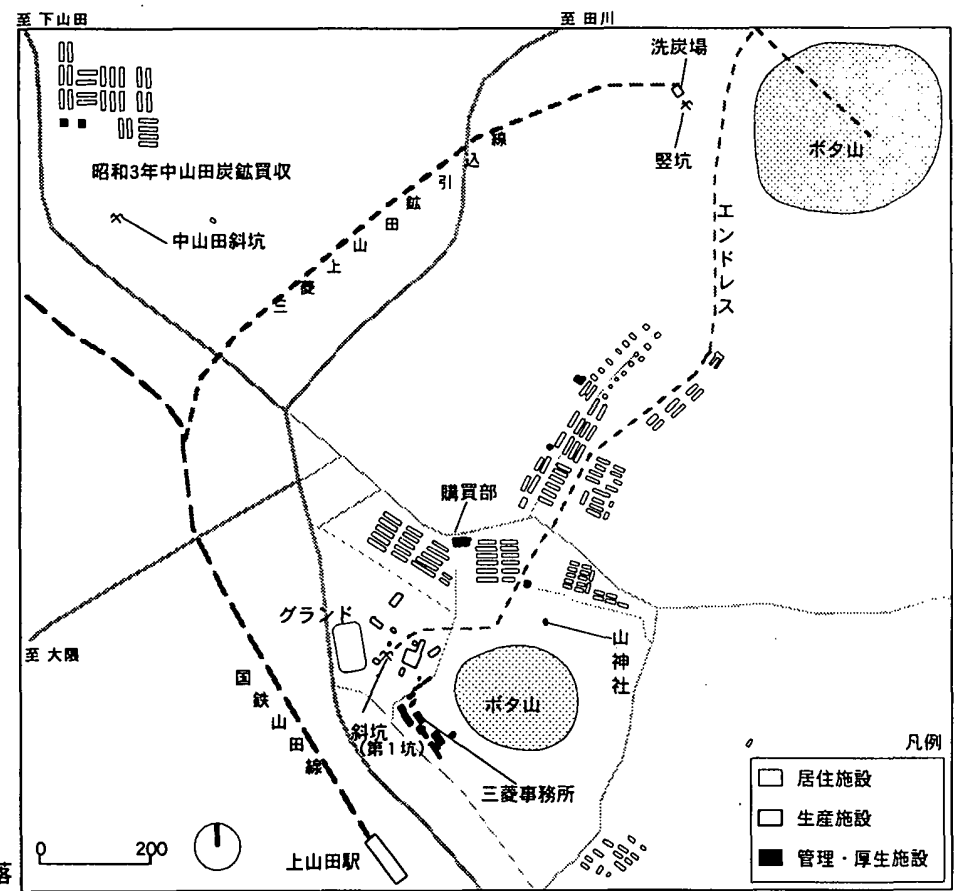




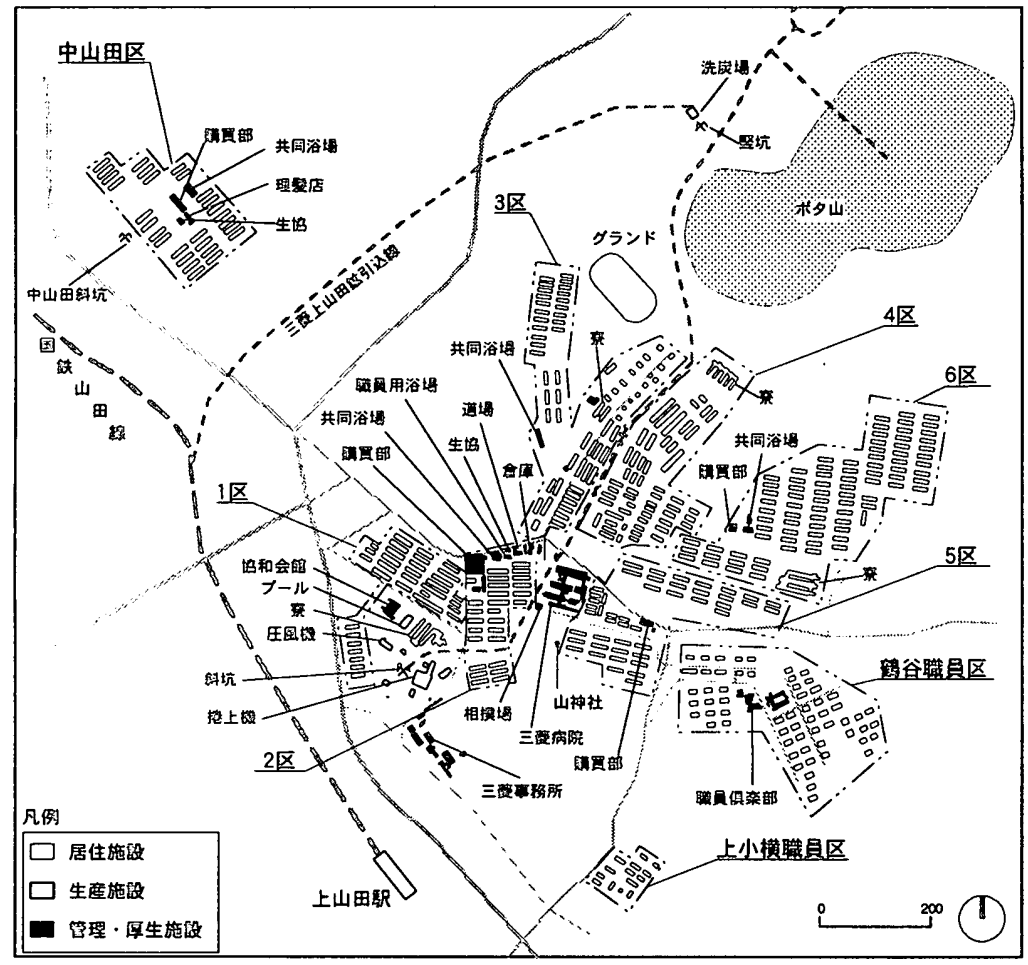

図 4 昭和 28 年の三菤上山田鉱 炭鉱集落

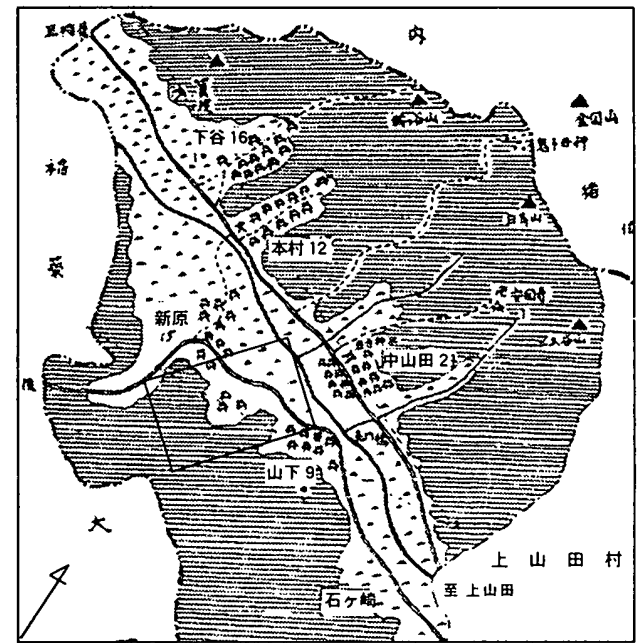

图 5 明治初期の下山田村

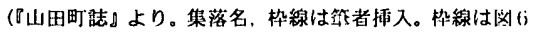
の筑围を示す。)

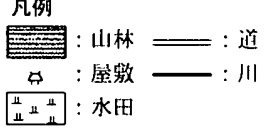

よって集落建設は単身者用の 4 つの尞だけである。

- 復興統制期（昭和 $20 \sim 24$ 年）

終戦によって多くの単身労働者が引き上げる一方，傾斜生産政策 によって復員者や引揚者などが家族を伴い流入した。三菱上山田鉱 は, 新しく土地を買収し造成を施して鉱員住宅ならびに職員住宅を建 設した。新しい地区はそれまでと比較にならないほど規模が大きく， そ扎らは新しく3つの区（5・6区，鶴谷職員区）を形成している（図 5)。

職員住宅は，北斜面という劣条件よりも，市街地との距離が優先 さ扎て計画されている。地区内には職員俱楽部などが配置されている が，購買部など衣食関連の施設は市街地に依存している。

釷員住宅は，融資基準に則った画一的な住戸が供給され，地区内 には購買部の支所や理贸店などが建設され, 集落内だけで最低限の独 立した生活ができる仕組みは継続している。

\section{一縮小期（昭和 25 年〜）}

三菱上山田鉣は同 37 年に閉山した。会社側は当初, 一時的な不況 と判断していたが, 昭和 29 年頃から認識を改め, 三菱鉱業では筑豊 の5鉱が老朽化炭鉱として問題視され，さらにそのなかで上山田鉱が 立地上，輸送コストがかかるため，早期閉山の方針が決定した $\left.{ }^{33}\right) 。$ よって縮小期には新しい住宅建設は行なわれていない。

\section{3-3 古河下山田炭鉱における集落建設}

\section{一萌芽期（～明治 26 年）}

下山田地域における炭層は三菱上山田鉣が押さえた鉣区ほどは優 良ではない。山田川の東側は断層が多く, 西側は断層は少ないが急傾 斜となっている。古河鉱業は西側の鉣区を買い取り, 明治 27 年に操 業を始める。それまでの下山田地区には狸掘り ${ }^{34}$ ) 程度の炭鉱が $3 つ$ あったという記録があるだけで, 本格的な炭鉱開発はまだ行なわれて いなかった ${ }^{35}$ )。下山田には既存集落が7つあり, 古河下山田鉱の炭 釷集落は 2 集落（新原〜山下）の間に立地した（図 5)。古河鉱業参 入時の村との契約書 ${ }^{36}$ ) を見ると, 水田や宅地の購入価格は山林の
10 倍以上に設定されている。山林に加えて水田や宅地にも敷地が及 んだのは, 駅との連続性から選択の余地がなかったことによると思わ れる。

一確立期（明治 $27 \sim$ 大正 7 年）

明治 31 年に発行された『筑豊炭鉱誌』 ${ }^{37}$ ) によると, 当時すでに 仮事務所, 鉄工所, 大工小屋, 運輸見張所, 現場監督詰所, 監裹方出 張所, 仮医局, 用度係事務室 (倉庫含, 日用品分配所併圈), 仮合宿 所兼駐在所，役宅 5 棟 (8戸)，工手納屋 2 棟（16戸), 鈗夫納屋 16 棟 (116戸) が建ち, 労働者は, 職員が所長以下 54 名（所長・支山 長・鉱務課・経理課・医員・準役員)，釷員が，常勤坑夫 350 名をは じめ仕繰方 30 名・唧筒方 20 名・棹取 20 名・選炭および運炭夫 60 名, それに小頭・鍛冶・大工・日雇人足となっていた $\left.{ }^{38}\right)$ 。開発から 3 年 あまりで, 仮施設が多いとはいえ一応の施設が建設され，労働者が確 保されている。

鉱員の生活管理は納屋頭によっていたが $\left.{ }^{39}\right)$, 古河下山田鉱では, 炭鉱集落内の鉱夫納屋の他, 付近の民家に借家する鉱員が多かった。 明治 39 年に調査が行なわれた『鉱夫待遇事例』40）によると，三菱

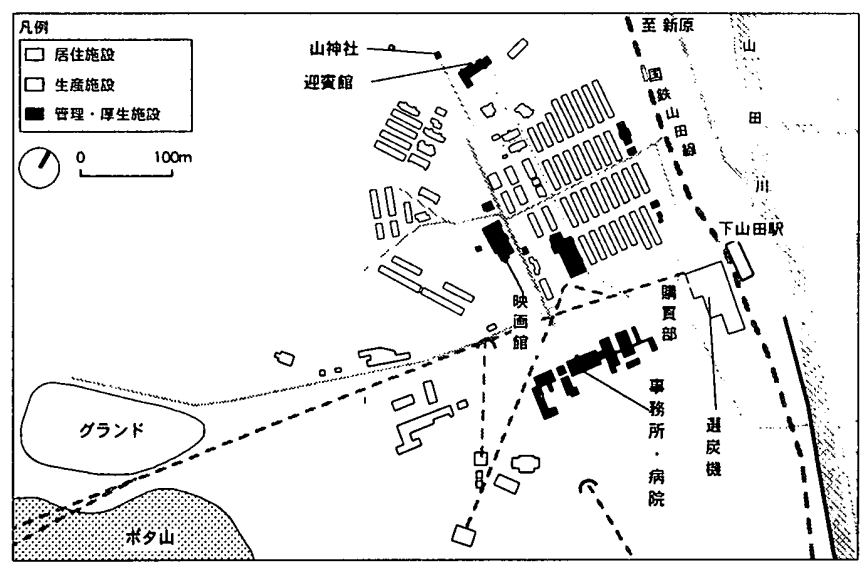

図6 昭和 7 年の古河下山田鉱 炭鉱集落 
上山田鉱では労働者 954 人のうち 130 人が借家住まいであるのに対 し, 古河下山田鉱は, 1,377 人のうち 784 人が借家, 45 人が自宅か らの通勤と半数以上を占めている。

また餅田地区にあった家族向け納屋は, 聞き取り調查によると, 閉 山時とほぼ同じように整然と配置されていたといい, 配置形態からこ の納屋建設は企業が行なっていたと考えられる。

娛楽・厚生施設は, 『鉱夫待遇事例』（明治 39 年調査）に娛楽場, 幼坚預かり所の建設計画があるとあり,三菱上山田鉱よりかなり早く に計画されている。

\section{一停滞期（大正 8 昭和 5 年）}

古河下山田鉱は, 昭和 4 年頃 ${ }^{41}$ ）にそれまでの鉱員住宅をクリア ランスし, 背後の丘陵地も合わせて, 娛楽・厚生施設や職員住宅, 鉱 員住宅が一体となった地区を建設している(図 6)。山神社と病院を 結ぶ中央の道沿いに娛楽・厚生施設群が配置され，その上の斜面上に 鉣員住宅地を見下ろすように扇形に職員住宅が建設されている。さら に鉣員住宅地区 (餅田) 内の通りには街路樹が植えられるなど（写真 2）他の炭鉱に見られない特徴がある。職員住宅地では上に行くほど 職階が上であったといい, 計画にあたって高低差を意識して配置して いることが分かる。厚生施設は, 大正 14 年までに購買会・託児所・ 医院・共斉組合 ${ }^{42}$ )，その後映画館・迎賓館などが建設されている。 この時期, 三菱上山田鈆では労働者を 4 分の 3 にまで減らして不況を 凌いでいるが, 古河下山田鉱は第一次大戦後の不況期に人員を減らし ておらず43), 新規坑口の開発を進めるなど, クリアランスを含め, 積極的な経営を行なっている。また,このような計画的な炭鉱集落建 設は, 同系列の他鉱でも見受けられる $\left.{ }^{44}\right)$ 。古河鉱業の母体の古河財 閥は鉱山業が中心の産業財閥であり, 総合財閥のように金融や貿易と いった多角的経営をしていない。鉱山業の経営に占める比重が大きい ことが, 労務管理面における納屋制度への取り組みを早くさせ, 計画 的な集落運営を志向させたと考えられる。

\section{- 軍需統制期（昭和 $6 \sim 19$ 年）}

古河下山田鉱は, 昭和 10 年の $\left.329,202 \mathrm{t}^{45}\right)$ をピークに出炭量が下 降している（図 1)。これは新しく開発に着手した炭層が見込み違い であったことにより, 昭和 11 年時点では, 新しい炭層の開発に着手 し，鉱員募集を強化している $\left.{ }^{46}\right)$ 。そのため鉱員住宅を次々と建設し
た（図 7)。新しく建設された地区は，昭和初期に建設された炭鉱集 落との連続性に乏しく, 飛び地となっている。このうち一片地区は 駅との標高差が $50 \mathrm{~m}$ もある場所, 宮ノ前地区は市街地内であるが坑 道によって陥没したために買い取っていた土地, 深見地区は地主か らの賃貸である。戦時中という時節柄, 余剩地を見つけて急造した ことがうかがえる。

太平洋戦争中の急増する単身労働者に対しては, 既存の長屋を寮 として運営したという。

\section{一復興統制期（昭和 $20 \sim 24$ 年）}

他鉱と同じく復興金融金庫から多額の融資を受けたものの, 融資 を住宅建設に充てていない。昭和 22 年度, 他の古河鉱業の 3 鉱は建 設費の $5 \sim 8$ 割を炭鉱住宅建設に充てているのに対し, 古河下山田 鉱は 2 割にすぎない $\left.{ }^{47}\right)$ 。この間の新規建設は 8 棟である。戦後の新 規流入者は，戦時中に建設した家族向けの鈗員住宅のストックで対 応できたことによると思われる。

一縮小期（昭和 25 年〜）

古河下山田鉣も三菱上山田鉱と同様, 新規建設はみられないまま 閉山する。しかし閉山時期は昭和 45 年と遅い。

4.まとめ

以上 $2 つ の$ 事例を通して，炭釷集落の建設過程を見てきた。

炭鉱集落建設を通時的に見ると, まず筑豊の場合は農村地帯を ベースとしているため, 参入時に両者とも山林を中心に立地してい る。それは既存の農村集落と距離を置くという意味の他に, 広い敷 地を必要とするため, 農業的価值が低く価格の安い土地が選ばれた と考えられる。その結果, 鉄道との関係から低地との接点をもち, 坑 ロに近い丘陵地に建設された。

両者とも炭鉱集落内には最低限の生活施設が内包さ㧈, 市街地と は独立した集落建設が意図されている。娛楽・厚生施設が集落の中 心に建設され, 閉山時の施設要素はほぼ共通している。しかし古河 下山田鉱では三菱上山田鉱に比べより早く擪生施設が登場しており， 納屋制度に取り組む時期とも対応している。

職員住宅においては, 両者とも鉱員住宅との階層差が単体の住戸 形式だけにとどまらず，立地にも反映されている。市街地が未整備 な時代は地形の高低差が職階を表し, ある程度市街地が整備される
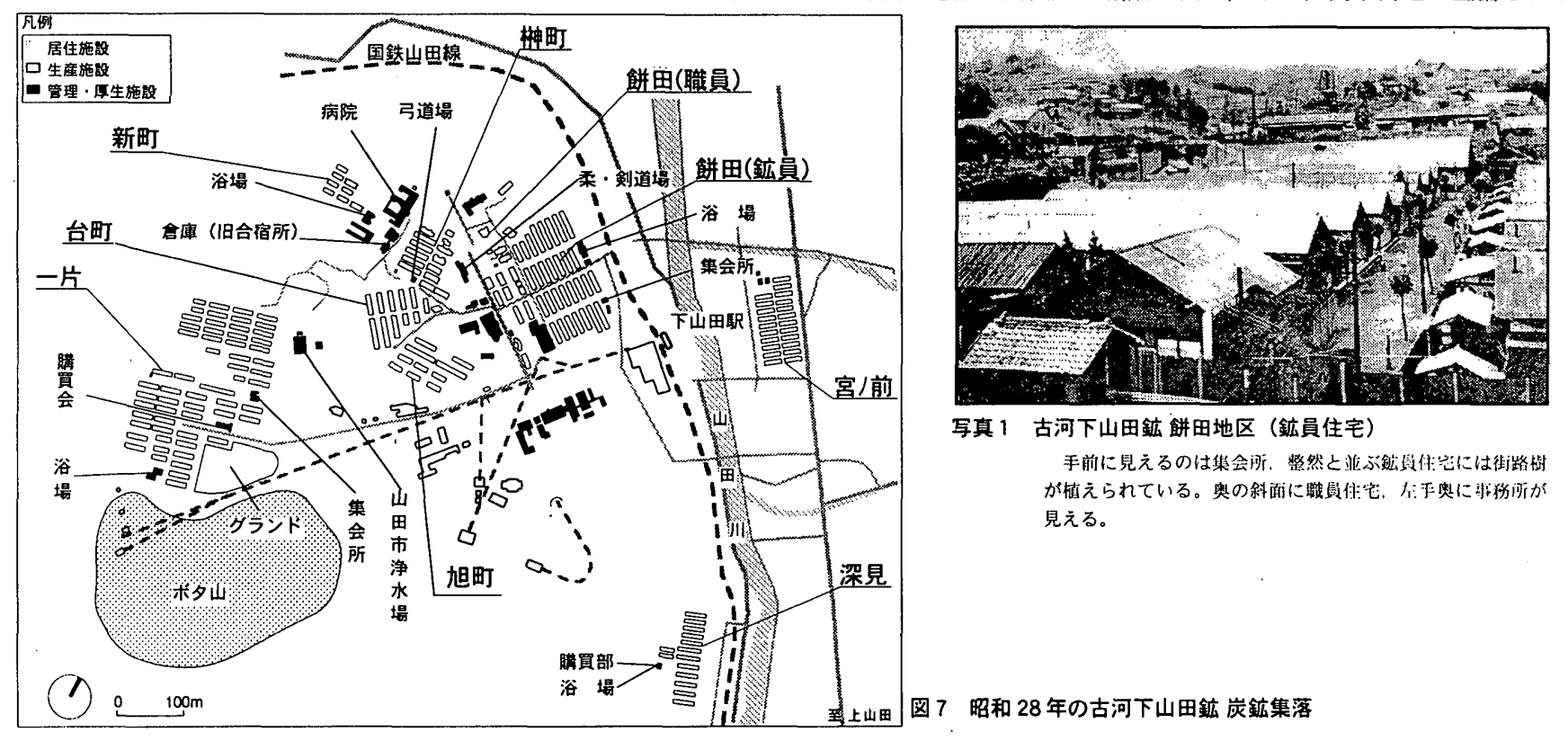

写真 1 古河下山田鉱鲜田地区（鉱員住宅）

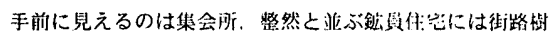

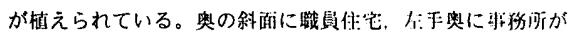
見える。

图 7 昭和 28 年の古河下山田鉱 炭鉱集落 
と市街地との近さが重視されている。

鉱員住宅は両者ともに初期に納屋制度が採用される。三菱上山田 鈗は, 廃止時期が遅いこと, 停滞期を経営を縮小することで凌いでい ることから,その後の開発が納屋を残したまま進められた。一方, 古 河下山田鉱では, もともと民間の借家が多く納屋が少なかったこと, 停滞期に穦極的な経営に踏み切つたこと,企業として計画的な炭釷集 落を志向したことなどから，大規模なクリアランスが実施され，一体 的な集落が新たに建設されたと考えられる。企業が独自に鉱員住宅を 運営・建設し得た時期は納屋制度廃止後から国の統制下に入るまでと 短い。この時期の労務管理や経営方針の違いが, 初期の空間構成に大 きな影響を与えている。

軍需統制に入る以前の住宅の建設量は両者とも生産量とほぼ比例 の関係にあるが, 軍需統制以降は復興統制期も含めて, 生産は国策と 連動し，建設は融資を受けることができるようになったため，一時期 に大量供給されるケースが出てきた。両者の開発状況は, 戦時下に供 給した古河下山田鉣では飛び地状に地区が分散し,戦後に供給した三 菱上山田鉱では造成を施した連続的な地区が建設されている。戦時下 と戦後という時勢の差が, 用地取得や造成期間の工期の差となって集 落空間にも表れているのである。

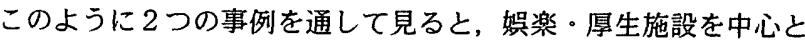
した自己完結的な炭鉱集落構成,そのなかで高低差や立地による地区 の階層化, 施設などの構成要素, と共通点も多い。しかしその空間棈 成は各時代の企業の労務管理を含めた経営上の指針に大きく左右され て形成されていることがわかる。

\section{付跑}

本研究は将成 $9 \sim 11$ 年度文部省科学研究費（基盤 C）の助成を得て行なわれた 研究の・部である。

铨

1)炭鉱集落は，地理学て炭鉣企業によって開発された地域を指すときに脒い られる。それに対し炭鉱町や炭鉱都市は市街地を含む地域・带を指す。

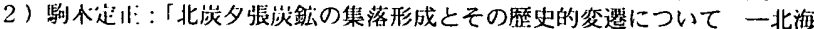

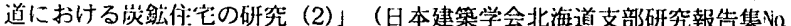
561983.3 所收。

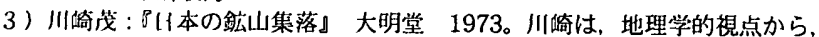

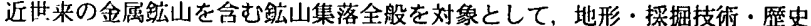
的背景から小集落の盛衰を論じている。その結果として, 鉣山集落の展開 は，地理条件や鉱脈といった自然条件に規定されている部分が大きく，経営 技術や経営方式による影は少ないとしている。

4）三菱鉱業々冲株式会社：『三菱鉱業社史』1976 年 付表 14 よると 15 釯 中第 8 位。

5) 【山田市役所：〔山田市」昭和 29 年

6 ) 一: 「山田町全図」 昭和 7 年

7) 1 日本帝国陸軍測是部：「後藤寺」昭和 2 年 $1 / 5$ 万

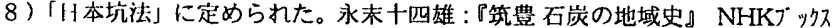
1973 によると，当時。下坪以下が 6 割以上を占め, 1 万坪以上は $2.5 \%$ にす ぎなかった。

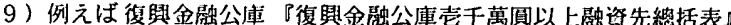

S23.12.31によると，融資総額 847 億円のうち，421 億円が石炭鉣業に充て

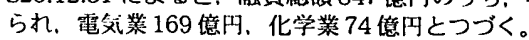

10）市原博：湠鈆労働者の社会史 日本の伝統的労僖・社会秩序と管理』多賀 出版 1997年，山本作兵衛『筑豊炭坑絵巻』萃書房昭和 48 年(「筑豊炭坑 物語」部分)などを参洘とした。

11 ）明治 20 年、福岡の『福陵新報』が納屋制度弹勃キャンベーンを張り，明

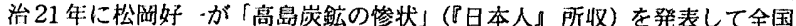
的な関心を集めるようになった。

12）前指永末十四雄 $\mathrm{p} 113$ によると，最も早く納屋制度発止に踏み切ったの は明治 32 年の明治炭鉱。これに明治 35 年，二井田川鉣が続き，直轄制へ移 行する䞨努となった。

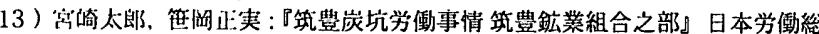

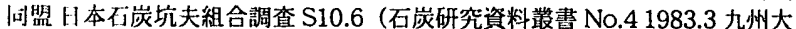

学石炭研究資料センター pp149〜所集）より。著者の宫崎は，明治 39 作ま

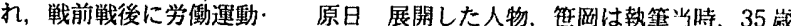
前後で日鐵二瀨中央炭鉣に勤務していた。

14 ) 前掲『三蒙捈業社史』 $\mathrm{p} 301$

15 ）高野江基太郎：『日本炭鉣誌』明治 44 年

16 ）前揭『三菱鉱業社史』p306。詰所制度とは経営家族主義的な方針であり， 区長に「钩夫生活中二心身共二透徽シ鉱夫ノ良キ父トナリ兄トナ」ることが 求められた。

17 ）(財) 日本経営史研究所：『創業 100 年史』古河鉣業株式会社: 昭和 51 年 18 ）前掲『創業 100 年史』p295

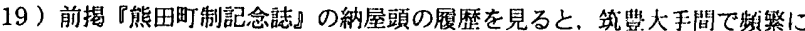

移動しており，炭鉣の固有性は少なかったと判断できる。

20 ) 前掲永末十四雄: 筑豊厅華炭鉱の社会史』p231より。

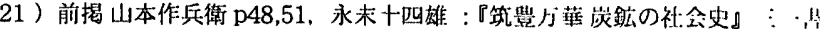
房 $1996 \mathrm{p} 232$

22 ) 前掲永末十四雄：『筑豐方華炭鉣の社会史』 $\mathrm{p} 232$ の新人鉣テー夕。

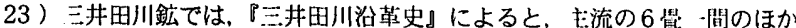
に，俊秀な鉣員用として $4.5+4.5$ 量や 階建（6+4.5 量）の俊等补它が建設

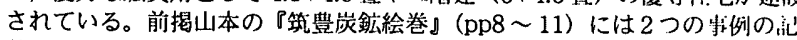

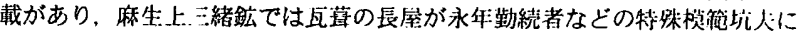

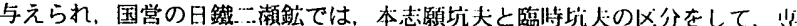
業鉣夫を優遇する策が取られていた。

24 ) 大日本帝国陸軍测量部「後滕寺」明治 33 作 5 年分の 1

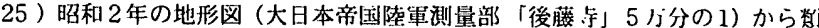
推することができると考えられる。なぜなら大正 7 年から吸和 2 和の間は，

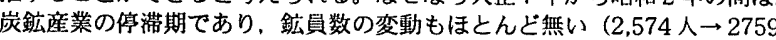

人，8三菱鉱叢社史』巻末付表より)。

26）吩通口木城鉣の閉山時に作成された「土地・建物評価次料」に三菱上山目 鉣時代の建物の記戥がある。

27 ）前揭『熊田町制記念誌』pp34 36

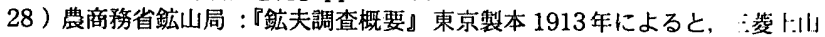
田鉣の鈗員 849 人のうち 759 人が納屋制度下の鉣員であった。

29 ）市原博：『炭鉱の労働社会史』多賀出版 1997 年 p169「世铦方は 46 人川

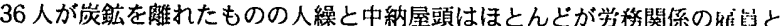
して再雇用された」。

$30 ）$ 昭和 2 年の地形図から判断できる。

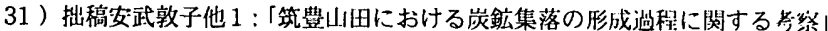
(『日本建築学会九州支部報告集』1997年3月 pp125〜128所收)，间 「企業の住宅運営の視点から見た炭鉱集落の空間形成フロセス 筑叟刂岆 山田炭鉣を通して」(『日本建築学会九州支部報告集』1999 年3月 pp105 ～ 108 所収)

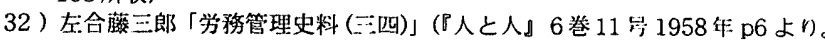

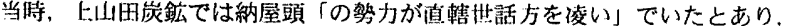
納厗頭の方が主流だったことがうかがえる。

33 ) 前掲『菱鉱業社史』 $\mathrm{p} 560-561$

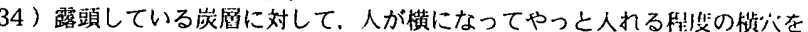
掘って採排することを狸掘りという。

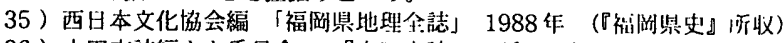

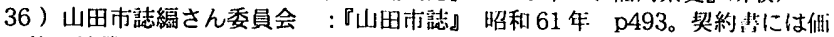
格や補伴について甾かれている。

37 ) 高野江基太郎：『筑豊炭鈜誌』明治 31 年（復刻 文献出版 昭和 50 年）

38 ）前掲 高野江基太郎（明治 31 年）より。仕繰方は坑内の天井を囲い，唧简 方は坑内の水を出し、棹取は坑内から石炭を運び出す仕事をする。浑炭夫は 切羽から坑内の主要道まで石炭を運ぶ。

39 ）農商務省鉣山局：『鉣夫待遇事例』明治 41 年（昭和 56 年の泰零堂書店に よる復刻版）の調查（明治 39 年）によると，古河下山畞鉣の生活管理は备 轄制度と納屋制度の 2 本立てであったが，その割合は，納屋制度のうが染 かったと思われる。大正 2 年発行の農商務省鉣山局：『鉙夫調查概要』東分 製本に，納屋制度と直轅世話方制度の割合 (男子鉱員数) が出ており，586 人 : 35 人となっている。

$40)$ 前揭『鉱夫調査概㱠』東京製本大正 2 年

41 ）聞取り調查より。鉣員住宅の再開発の年代 : 昭和 4 年は、話者の父視の 年令から㳰かれたものである。

42 ）前掲: 『創業 100 年史』古河鉙業株式会社 p391 表第 4-9

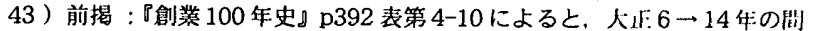

に，古河鉣業が経営する 3 鉱のうち他の 2 鉱では，好間鉣： 3,033 人 $\rightarrow 733$

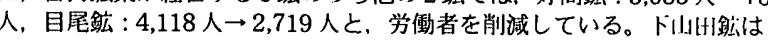

1,125 人 $\rightarrow 1,285$ 人の微增である。

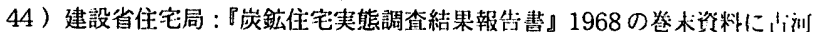

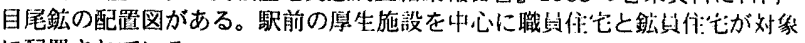
に配置されている。

45 ）『本邦鉙業の盗煍』より。

46 ）前掲『創業 100 年史』 $\mathrm{p} 433$

47 ）前揭『創業 100 年史』。1鉱增は大峰鉣を嘪收したことによる。

(2000年 7 月 10 日原稿受理, 2000 年 9 月 18 日採用決定 